\title{
THE SPONTANEOUS CROSS-POLLINATION OF SEVERAL HEXAPLOID TRITICALE VARIETIES IN THE EXPERIMENT OF 2012-2013
}

\author{
Alexey Valeryevich Shirokolava ${ }^{1 *}$, Valentina Sergeevna Rubets ${ }^{1}$, \\ Vladimir Valentinovich Pylnev ${ }^{1}$
}

\begin{abstract}
Summary
In this study, the spontaneous hybridization ability of the hexaploid triticale varieties with the other triticale varieties, and with wheat and rye, were considered. The influence of biological and technical contaminations on the cultivar's purity had been studied. It was shown, that the probability of cultivar pollination in triticale crops is considerably higher, than the probability of inter-species pollination.
\end{abstract}

Key words: Triticale, spontaneous hybridization, biological contamination

\section{Introduction}

Formally being a self-pollinated crops, triticale is actually able to cross-pollinate both with other varieties of the same crops and with the parental species (wheat and rye). This ability may make difficult the selection and breeding process of triticale (Rubets et al., 2011). Thus, in accessions obtained, hybrid forms, disposed to subsequent cleavage, may be present, and varietal crops are at constant risk of biological contamination (Kurkiev, 2000; Pavluk et al., 2006).

At present, spatial isolation norms, equal to 150 meters (The instruction for approbation of breeding crops, 1996) have been established for triticale. Considering that the issue of existing triticale forms propensity to spontaneous hybridization is still unclear, the given isolation norms cannot fully meet the requirements of breeding programs. The further study of triticale's xenogamy frequency may improve the methods of working with this crop, and the quality of seed crops.

This work is dedicated to evaluate spontaneous hybrids occurrence frequency in some triticale forms and to study their actual exposure to biological contamination.

\section{Materials and methods}

The studies were conducted at the De-

\footnotetext{
Original scientific paper (Originalni naučni rad) ${ }^{1}$ Shirokolava A.V.*, Rubets V.S., Pylnev V.V.,Department of selection and seed-field crops of RSAU - MAA named after K.A. Timiryazev Timiryazevskaya street 49, 127550 Moscow, Russian Federation. 
partment of selection and seed-field crops of RSAU - MAA named after K.A. Timiryazev in 2011/2012 and 2012/2013 seasons. The experimental crops were located on the fields of Lysytsyn's plant breeding station. The cultural practices used were common for the area. (Pylnev et al., 2005).

Meteorological conditions during the experiment period varied slightly, and, in general, corresponded to annual data, obtained from the V.A. Michelson's meteorological observatory, only with the minor excess of average monthly temperatures in 2013 . The amount of rainfalls for the spring-summer period in 2012 and 2013 exceeded the average long-term rate.

Several forms of winter hexaploid triticale with recessive traits (namely, the white spike color and the lack of pubescence on spike glumes), the Valentin, 21759/97 line and Hermes, were used in experiment. The winter triticale cultivar Vodoley with dominate traits red spike color and spike glumes pubescence along with the winter diploid rye Alpha, winter tetraploid rye Veryasen and hexaploid winter wheat varieties Moskovskaya 39 and Harmony were used as pollinators (potential contaminators).

The check samples were planted in alternating rows (a parent brand: a pollinator). In some cases, the adjacent rows of the main varieties and potential pollinator were isolated in pairs by large parchment insulators $(150 \mathrm{x}$ $90 \times 15 \mathrm{~cm}$ ) attached at the ends of the rows with metal rods (Fig. 1). Those isolators were removed after safeguarded triticale flowering completion, thus ensuring the absence of extraneous biological contamination.

The seeds obtained in the first season were harvested manually and planted on separate plots with an area of 5 square meters $\left(5 \mathrm{~m}^{2}\right)$ each in autumn 2012.

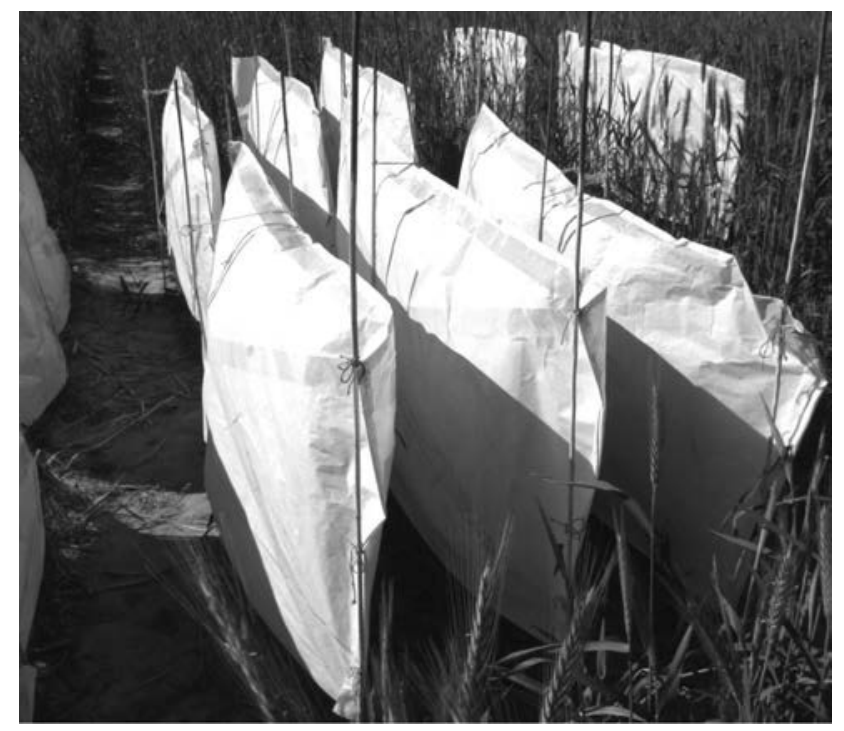

Fig. 1. The picture of the large parchment isolators in the field Slika 1. Fotografija tehničke izolacije u polju 
After maturation all recessive forms were harvested manually with a sickle. The sheaves were analyzed according to an approbation type, their varietal purity were defined and compared with the standards of GOST R 52325-2005, and the effect of spontaneous pollinations with other varieties of triticale and parental species were estimated.

\section{Results and Discussion}

To sum it up, 49520 productive shoots of three recessive triticale forms were obtained during the field experiment from 104 experimental plots -52 variants in 2 replications. 490 of them were hybrid forms due to cross-pollination with the experimental contaminators.

Table:1. The results of the field experiments of spontaneous winter hexaploid triticale hybridization in the period of 2012-2013.

Tabela 1. Rezultati spontane hibridizacije ozimog heksaplodnog tritikalea u poljskom ogledu 2012-2013.

\begin{tabular}{|c|c|c|c|c|c|}
\hline Main variety & Potential pollutant & $\begin{array}{l}\text { The main va- } \\
\text { riety, totally }\end{array}$ & $\begin{array}{c}\text { Hybrids, } \\
\text { totally }\end{array}$ & $\begin{array}{l}\text { Atypical } \\
\text { forms, } \%\end{array}$ & $\begin{array}{c}\text { Varietal } \\
\text { purity, } \%\end{array}$ \\
\hline Valentin & Alpha & 2355 & 0 & 0 & 100,00 \\
\hline Valentin & Veryasen & 2484 & 0 & 0 & 100,00 \\
\hline Valentin & $\begin{array}{l}\text { Vodoley (w/o } \\
\text { isolation) }\end{array}$ & 5251 & 134 & 2,49 & 97,51 \\
\hline Valentin & $\begin{array}{r}\text { Vodoley (with } \\
\text { isolation) }\end{array}$ & 2410 & 47 & 1,91 & 98,09 \\
\hline Valentin & Harmony & 1779 & 0 & 0 & 100,00 \\
\hline Valentin & Moskovskaya 39 & 1501 & 1 & 0,07 & 99,93 \\
\hline Hermes & Alpha & 1533 & 0 & 0 & 100,00 \\
\hline Hermes & Veryasen & 3295 & 9 & 0,27 & 99,73 \\
\hline Hermes & $\begin{array}{l}\text { Vodoley (w/o } \\
\text { isolation) }\end{array}$ & 8419 & 137 & 1,60 & 98,40 \\
\hline Hermes & $\begin{array}{r}\text { Vodoley (with } \\
\text { isolation) }\end{array}$ & 3374 & 82 & 2,37 & 97,63 \\
\hline Hermes & Harmony & 3320 & 0 & 0 & 100,00 \\
\hline Hermes & Moskovskaya 39 & 2156 & 0 & 0 & 100,00 \\
\hline 21759/97 line & Alpha & 2192 & 0 & 0 & 100,00 \\
\hline 21759/97 line & Veryasen & 1286 & 18 & 1,38 & 98,62 \\
\hline 21759/97 line & $\begin{array}{r}\text { Vodoley (w/o } \\
\text { isolation) }\end{array}$ & 1465 & 62 & 4,06 & 95,94 \\
\hline 21759/97 line & Harmony & 2864 & 0 & 0 & 100,00 \\
\hline 21759/97 line & Moskovskaya 39 & 3346 & 0 & 0 & 100,00 \\
\hline
\end{tabular}

The table shows that, in accordance with theoretical expectations (Maximov N.G., 1986, Titarenko et al., 2010), the highest frequency of spontaneous hybridization was observed between varieties with recessive traits and the variety Vodoley with dominant traits.

In each combination where Vodoley was used as a pollinator, a certain percentage of hybrid forms were attended. The value of such percentage varied from $0.31 \%$ to $4.37 \%$. These 
data confirm the earlier findings, that spontaneous hybridization is possible between the different hexaploid triticale varieties. (Rubets et al., 2013)

It is of interest that in the combination with isolation experiments where Valentin was used as a potential pollutant, the frequency of spontaneous hybridization was approximately $0.5 \%$ greater than in the same combination without isolation. When the Hermes was used as a potential pollutant, the different trend may be observed: the percentage of hybrid forms in combinations, where isolation was used, was $0.77 \%$ less than in combinations without insulation.

The interspecies hybridization was observed less often. The percentage of hybrid forms in combinations with rye ranged between $0.23 \%$ and $1.46 \%$. All the occurrences of triticale-rye hybrids were observed only when the tetraploid rye variety Veryasen was used as a pollinator. There were no cases of spontaneous hybridization observed with the diploid rye variety Alpha as a pollinator, which are in accordance with theoretical expectations (Titarenko et al., 2010).

The spontaneous interspecies hybridization with wheat was observed just in one case, in combination of the triticale variety Valentin with the wheat variety Moskovskaya 39. There was only one plant found, that was reliably identified as a hybrid of those forms. There were no cases of spontaneous hybridization with the Harmony wheat variety.

In any case, the percentage of hybrids from the spontaneous cross-pollination did not exceed 5\%, which would have reduced the varietal purity below the conditioned guidelines. The highest percentage of spontaneous crosspollination, noted during the course of the experiment, was observed on the combinations of line 21759/97 x Vodoley without isolation $(4.37 \%)$, and Valentin $x$ Vodoley without isolation $(4.1 \%)$. Thus, the varietal purity of crops in any cases did not fall below 95\%, determined by GOST R 52325-2005 (GOST RF) as a norms in seed production. However, about half of the experimental plots - 36 of 78 -were contaminated by hybrid forms due to spontaneous cross-pollination at the rate of $0.5 \%$ or more, which exceeded the allowable norms of varietal purity for the original seed. In 32 cases out of 78, contamination by hybrid forms was higher than $0.8 \%$, while the requested rate of varietal purity for elite seeds, according to GOST is $99.8 \%$ (Parachin et al, 2006, GOST $\mathrm{RF})$. The average fouling throughout the experiment was $1.89 \%$ when the variance was 1.43 .

It would be interesting to compare the experiment data obtained in 2012-2013 with the data, obtained in 2011-2012, when grain setting in winter triticale spike under spontane-

Table 2. The spontaneous cross-pollination of winter triticale line 21759/97 with other triticale variety (Vodoley) and rye (Veryasen) in 2011-2012 and 2012-2013 experiments

Tabela 2. Spontana ukrštanja ozime linije tritikalea $21759 / 97$ sa drugim varijetetom tritikalea (Vodoley) $i$ raži (Veryasen) u periodu 2011-2012 i 2012-2013.

\begin{tabular}{lcccc}
\hline & \multicolumn{2}{c}{ Study of 2011-2012 } & \multicolumn{2}{c}{ Study of 2012-2013 } \\
\hline \multirow{2}{*}{ Combination } & $\begin{array}{c}21759 / 97 \times \\
\text { Vodoley }\end{array}$ & $\begin{array}{c}21759 / 97 \times \\
\text { Veryasen }\end{array}$ & $\begin{array}{c}21759 / 97 \times \\
\text { Vodoley }\end{array}$ & $\begin{array}{c}21759 / 97 \times \\
\text { Veryasen }\end{array}$ \\
\hline Total productive shoots & 3334,00 & 1262,00 & 1465,00 & 1268,00 \\
Hybrid forms & 76,00 & 23,00 & 62,00 & 18,00 \\
Percentage, $\%$ & 2,28 & 1,82 & 4,06 & 1,38 \\
\hline
\end{tabular}


ous cross-pollination with other varieties and parental species were studied (Pylnev et al., 2005. Rubets et al, 2011)

Due to the available data, it can be noted that the percentage of hybrid forms in $21759 / 97$ x Vodoley combination, increased by $1.78 \%$, and in $21759 / 97 \times$ Veryasen combination decreased by $0.44 \%$ compared to previous year. The reason for occurring modifications is still not exactly clear, but it can be explained due to climatic conditions differences during both experiments: in particular, there was severe drought in the phase of full bloom in 2011, and heavy rainfall in the same period of 2012.

It is known that the high air humidity and cloudy weather increases the viability of pollen, the percentage of open flowering, and the risk of spontaneous cross-pollination in self-pollinated crops. On the other hand, the high temperature reduces the viability of pollen, and drought reduces the plants susceptibility to the pollen (Waines J.G., Hegde S.G., 2003).

The work will be continued in order to obtain data for several years of the experiment, which will allow to make complete statistical comparasion. In 2013, series of crosses have already been carried out, the results of which will be obtained and analyzed in 2014 .

\section{Conclusion}

1) The relatively high (up to $4.37 \%$ ) probability of triticale crops spontaneous cross-pollination in the field was confirmed.

2) The varietal pollination is the most dangerous type of triticale's biological contamination.

3) There is a chance for triticale to the spontaneous cross-pollination with rye, Tetraploid rye being much more likely to interbreed with triticale than diploid.

4) The probability of spontaneous crosspollination with wheat is extremely small.

5) The degree of crops contamination was within normal range only for generation's seeds.

\section{Acknowledgements}

The author would like to thank Rubets V.S. for her help, and T.N. Fomina, for her help in translating this article.

\section{Literature}

The instruction for approbation of breeding crops. Part 1 (grains, cereals, pulses, oilseeds and spinning culture). M.: VNIITEI Agroprom, 1996. $84 \mathrm{p}$.

Parachin NV, Kobzoev IV, Gorbathcev IV (2006): Forage prodiuction - M: KolosS, $432 \mathrm{p}$.

Kurkiev UK (2000): "The actual problems of triticale selection and new material creation", The works of practical botany, selection and genetics, SpB,. VIR. - T. 158. - C. 44-58.

Maximov NG: (1986) Plant Breeding and genetic characterization of hexaploid triticale hybrids with diploid and tetraploid rye. Genetics of heterosis plants and experimental mutagenesis. Part 2, Abstracts of the V Congress of Geneticists and Breeders of Ukraine, C.124-125.

Национальный стандарт РФ ГОСТ Р 52325 2005 “Семена сельскохозяйственных растений, сортовые и посевные качества: общие технические условия". Москва, Стандартинформ.

Pavljuk NT, Shevchenko V, Gregory II, Goncharov SV, Shvyrev YV, Aleshchenko AM (2006): New varieties of winter triticale - an important reserve 
for increasing productivity. Biological bases and methods of breeding and seed crops, Voronezh.

Pylnev VV, Konovalov YB, Hupatsariya TI (2005): Pylnev VV The breeding of field crops, Moscow: Kolos, 552 c.

Rubets VS, Pylnev VV, Mitroshina OV, Shirokolava AV (2013): Spontaneous cross-pollination of winter hexaploid triticale. News of the TAA,T.4.

Rubets VS, Pylnev VV, Nikitina EA (2011): The characteristics of cross-pollination in hexaploid winter triticale varieties. Agro-XXI, publ Agrorus. 11-14.
Titarenko AV, Titarenko LP, Kozlov AA (2010): Hybridization efficiency of winter rye with hexaploid triticale. Triticale. Proceedings of the international scientific-practical conference "The Role of triticale in the stabilization and increase the production of grain and fodder" and section offices triticale crop RAAS: Rostov-on-Don. Pp. 161-165.

Waines JG, Hegde SG (2003)// Intraspecific gene flow in bread wheat as affected by reproductive biology and pollination ecology of wheat flowers // Crop Sci. 2003. 43. P. 451-463. 


\title{
СПОНТАННАЯ ГИБРИДИЗАЦИЯ НЕКОТОРЫХ ФОРМ ГЕКСАПЛОИДНОГО ТРИТИКАЛЕ В ОПЫТЕ 2012-2013 ГОДОВ
}

\author{
Широколава Алексей Валерьевич, Рубец Валентина Сергеевна, Пыльнев \\ Владимир Валентинович
}

\section{Резюме}

Рассматривается спонтанная гибридизация трех форм гексаплоидного озимого тритикале как с другими сортами, так и с пшеницей и рожью. Также, рассматривается влияние биологического и технического засорения на сортовую чистоту посевов тритикале. Установлено, что вероятность перекрестного опыления внутри сорта тритикале гораздо больше, чем веороятность спонтанного межвидового скрещивания.

Ключевые слова: тритикале, биологическое засорение, спонтанная гибридизация,

\section{SPONTANA HIBRIDIZACIJA NEKOLIKO FORMI HEKSAPLOIDNOG TRITIKALEA U OGLEDU 2012/2013 GODINE}

\author{
Shirokolava Alexey Valeryevich, Rubets Valentina Sergeevna, \\ Pylnev Vladimir Valentinovich
}

\section{Izvod}

Ispitivana je spontana hibridizacija tri forme heksaploidnog tritikalea kako sa drugim sortama tritikalea tako i sa sortama pšenice i raži. Takođe je ispitivan uticaj biološke i tehničke kontaminacije na sortnu čistoću useva tritikalea. Utvrđeno je da je verovatnoća stranooplodnje unutar sorte tritikalea daleko veća od verovatnoće spontanog inter-species ukrštanja.

Ključne reči: tritikale, biološka kontaminacija, spontana hibridizacija 